\section{OBSERVATIONS ON THE EXAMINATION OF} SWIMMING.BATH WATER

\author{
BY
}

J. A. BRAXTON HICKS, M.D., M.R.C.P., D.P.H.

GROUP PATHOLOGIST (L.C.C.) LAMBETH HOSPITAL ; LATE DIRECTOR, JOHN BURFORD CARLILL LABORATORIES, WESTMINSTHR HOSPITAL; LATE BACTERIOLOGIST TO WESTMINSTER CITY COENCH

R. J. V. PULVERTAFT, M.D., M.R.C.P.

DIRECTOR, JOIN BURFORD CARIILL LABORATORIFS, WESTMINSTER HOSPITAL ; HACTERIOLOGIST TO WESHMINSTER CITY COLNCIL AND

F. R. CHOPPING

SENIOR TFCHNICAL ASSISTINT, WLSTMINSTER HOSPITAL

While no official standards of purity of the water of swimming pools are available, the general principles of examination are well established. It is desirable that the total number of organisms should be as low as possible, and that pathogenic strains should be absent.

The actual number of bacteria present is, however, by no means easy to ascertain. The apparent number varies with the depth at which the water is collected, the type of medium employed for culture, and the temperature and period of incubation. Where, as is now usual, bactericidal substances are added to the water the time elapsing between collecting and testing is very important. Moreover, the inhibiting power of one type of organism in a culture on the growth of others is very well known to bacteriologists, but is not generally taken into account. For example, the selection of MacConkey's medium or litmus lactose agar in the culture of faeces may frequently determine whether or not streptococci are grown. The inhibiting power of moulds is particularly marked, and moulds are always prominent in bath-water specimens. In our opinion standard methods of swimming-bath analysis greatly underestimate bacterial numbers. The medium used is normally a simple broth agar ; no serum or blood is added.

Thresh, Beale, and Suckling state: "It would be useless attempting to discover the specific organisms of these diseases (that is, pneumonia, tonsillitis, syphilis, etc.) in any water; we can only make certain that a water is practically free from the typical, most abundant, and most easily recognizable bacteria of excretal origin.' These authors quote many instances of the incrimination of bath water in respiratory disorders and in otitis media and it would appear to be reasonable to test specifically for such organisms as the streptococcus, the pneumococcus, and Staphylococcus aureus as common pathogenic throat organisms. Since, however, the water of swimming baths is to-day usually chlorinated, the test for the faecal strains becomes more logical, though, as will later be suggested, by no means exhaustive. It is generally accepted that such strains are the most resistant to chlorine; if they are killed the pyogenic group are not likely to survive. The efficacy of chlorination, or any form of disinfection, however, depends to an unpredictable degree on the medium in which organisms are suspended ; and no valid conclusions can be drawn from systems not identical.

Where no method of disinfection of swimming-bath water is used we have invariably found faecal strains in large numbers, and in one case haemolytic streptococci. The faecal strains isolated are in themselves innocuous; but their isolation is no measure of the presence or absence of the pyogenic organisms which clinical experience appears to suspect.

In this paper an account is given of the examinations performed during the past three years on the three public baths in the Westminster City Council area. They were among the first to be fitted with chlorination and filtration plants under the direction of Dr. A. Shinnie, to whose constant help and interest we owe the facilities for the examinations recorded. The results of examination of a control series of non-chlorinated baths have also been taken into account. The technique used is given in a footnote*; it must be emphasized that it was directed only towards the detection of faecal strains and streptococci, as well as total bacterial population. The isolation of pyogenic organisms other than streptococci was not attempted, and this paper is merely a study of the efficacy of chlorination and filtration methods in a representative series of London baths, according to standard criteria.

\section{Review of Material}

A number of competitive systems of disinfection are in common use. The water is always continuously flowing ; it enters at the shallow end, and is removed at the deep end. The speed of flow varies, but is usually such that a complete " turnover" is obtained in from four to six hours. Aluminium salts are added to precipitate organic matter ; the reaction of the water is kept alkaline, and after filtration through sand and oxygenation by an air blast, chlorine gas is continuously added just before the inlet.

\section{Chlorine Content and its Testing}

The difficulty of maintaining a proper concentration of chlorine is obvious. In very hot weather it was not possible to keep the chlorine concentration above $\mathbf{0 . 3}$ part per million owing to rapid evaporation. Moreover, the only method of estimation which is commonly employed is a colorimetric one, the concentration of chlorine being found by the colour produced by the addition of tolidine. Although the Ministry of Health report states that a concentration of 1.3 parts per million of chlorine is innocuous, this is very far from true. Such a concentration produces instant smarting of the eyes and a most unpleasant and persistent interference with the sense of taste and smell, lasting in some individuals for forty-eight hours. Our experience is quite definite that bathers will not tolerate a higher concentration than 0.5 part per million. Complaints are universal when this point is exceeded. Moreover, our results show that no concentration above this point is necessary. The dangers of over-chlorination are certainly as definite as those of under-chlorination. The tolidine method is, however, of doubtful value in the hands of unskilled workers. The colour developed varies directly with the time elapsing after the addition of tolidine. It is essential to make readings after precisely the same time. Again, the difference in colour intensity of the comparator tubes is very slight, even between the limits of 0.2 and 0.5 part per million. Thresh, Beale, and Suckling accept the limits of 0.2 part and 0.4 part per million as suitable.

As our observations indicate that below 0.3 part bacteria are not killed sufficiently quickly, and that above 0.5 part eye irritation is marked, it is desirable that some more delicate and simple method of chlorine control should be introduced. Investigations on this line are being made.

\section{* Tecuntor of Fximiraton of Bith Waters}

1. Put $2 \mathrm{c.cm}$. of the water into a sterile Petri dish with a sterile pipette; add 15 c.c.m. nutrient agar, melted and cooled to $45^{\circ} \mathrm{C}$. Mix, and allow to set. Repeat procedure with $1 \mathrm{c.cm}$. of water. Incubate at $37^{\circ} \mathrm{C}$

2. Add to bile salt broth, with Durham's tubes, 5 c.cm., 2 c.cm. $1 \mathrm{c.cm}$., and $0.5 \mathrm{c.cm}$. of water. (The $5 \mathrm{c.cm}$. is added to doublestrength broth.)

3. Add $25 \mathrm{c.cm}$. of water to bottle containing $100 \mathrm{c} . \mathrm{cm}$. litmus milk; heat in water bath at $80^{\circ} \mathrm{C}$. for ten minutes; pour on sterile liquid paraffin to about half-inch depth.

4. Centrifuge two $10 \mathrm{c} . \mathrm{cm}$. tubes of water, repeating three times. Pour off supernatant fluid; inoculate glucose broth tubes from deposit in one tube, examine the deposit in other tube for debris, cells, bacteria, spores, protozoa, etc.

5. Count colonies on plates after twenty-four and forty-eight hours' incubation. Examine bile salt broth for lactose fermenters and plate out if necessary. Examine litmus milk for foaming clot. Examine glucose broth tubes for streptococci. 


\begin{tabular}{|c|c|c|c|c|c|c|c|c|c|c|c|}
\hline & & & & & & : & TABLE & of Results & & . & \\
\hline Bath & Date & Time & $\left|\begin{array}{l}\text { No of } \\
\text { Bathers }\end{array}\right|$ & $\boldsymbol{p} \mathrm{H}$ & $\begin{array}{c}\text { Chlorine } \\
\text { in Parts } \\
\text { per } \\
\text { Million }\end{array}$ & $\begin{array}{c}\text { Quanti- } \\
\text { tative. } \\
\text { Colonies } \\
\text { in c.cm. }\end{array}$ & B. coi $i$ & Streptococci & B. welchii & Centrifuged Deposit & Remarks \\
\hline No. 1 & $24 / 7 / 20$ & 3.0 p.m. & 581 & $?$ & $?$ & 11 & Nil in & Nil & Nil & Almost nil, a few epithelial & - \\
\hline $\begin{array}{l}\text { 1st c'ass } \\
\text { No. 1 }\end{array}$ & " & $"$ & 180 & $?$ & $?$ & 3 & $\begin{array}{c}5 \mathrm{c.cm} . \\
.,\end{array}$ & $"$ & Nil $\left(B .8 u^{\prime}\right)$ & $\begin{array}{l}\text { cells } \\
\text { Fair No. of epithelial cells }\end{array}$ & - \\
\hline $\begin{array}{l}\text { 2nd class } \\
\text { No. } 2 \\
\text { 1st class }\end{array}$ & $29 / 7 / 30$ & 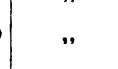 & 231 & 7.4 & 0.2 & 2,000 &, & Copious & $\begin{array}{c}\text { tilis) } \\
\text { Nil }\end{array}$ & A few cells, yeasts, many & $\begin{array}{l}\text { B. fluvescens present. } \\
\text { Outfall pipes later }\end{array}$ \\
\hline No. 2, & ", & " & 105 & 7.2 & 0.5 & 9 & " & Nil & ", & A few cells. No yeasts & found badily fouled \\
\hline 2nd class & $8 /: 0 / 30$ & , & 285 & 7.3 & Bath 0.35 & $120^{\prime}$ & $"$ & Fair No. & ", & A few cells. Spores & 85 of the colonies \\
\hline $\begin{array}{l}\text { 1st class } \\
\text { No. } 2 \\
\text { 2nd class }\end{array}$ & , & " & 104 & 7.2 & Bath 0.6 & No & No & No growth & , & A few cells. Hairs & $\begin{array}{l}\text { were l'en.g:aucum. } \\
\text { Bathers complained }\end{array}$ \\
\hline $\begin{array}{l}\text { 2nd class } \\
\text { No. l, } \\
\text { lst class }\end{array}$ & $21 / 10,30$ & " & 457 & 7.3 & 0.4 & 186 & $\begin{array}{l}\text { Nil in } \\
5 \text { c.cm. }\end{array}$ & $\begin{array}{l}\text { Mixed growth, } \\
\text { sone strept. }\end{array}$ & $"$ & A few cells. Vegetable matter & $\begin{array}{l}\text { of chlorine. } \\
112 \text { of the colonies } \\
\text { moulds. }\end{array}$ \\
\hline $\begin{array}{l}\text { No. 1, } \\
\text { 2nd class }\end{array}$ & " & $"$ & 159 & 7.4 & 0.4 & 134 & $\begin{array}{c}\text { b c.cm. } \\
\quad "\end{array}$ & $\begin{array}{c}\text { some surept. } \\
\text { Nil }\end{array}$ & 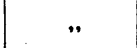 & Almest nil & - \\
\hline $\begin{array}{l}\text { 2nd ciass } \\
\text { No. } 2, \\
\text { lst class }\end{array}$ & $31 / 12 / 30$ & " & 74 & 7.6 & 0.4 & 292 & $"$ & $"$ & $"$ & $"$ & $\begin{array}{l}180 \text { of the colonies } \\
\text { moulds. }\end{array}$ \\
\hline $\begin{array}{c}\text { No. } 1, \\
\text { 1st class }\end{array}$ & $23 / 33$ & ", & 147 & $\begin{array}{l}\text { Top 7.2 } \\
\text { Bot. 7.3 }\end{array}$ & $\begin{array}{l}\text { Top } 0.5 \\
\text { Bot } 0.35\end{array}$ & 208 & " & Moderate & ", & Fair No. of cells and spores & $\begin{array}{l}\text { moulds. } \\
174 \text { of the colonies } \\
\text { moulds. }\end{array}$ \\
\hline $\begin{array}{l}\text { No. 2, } \\
\text { 2nd class }\end{array}$ & $25 / 3 / 31$ & " & 241 & $\begin{array}{l}\text { Top } 7.5 \\
\text { Bot. } 7.5\end{array}$ & $\begin{array}{l}0.45 \\
0.2\end{array}$ & 94 & $"$ & A few & $"$ & $" \quad$ " & $\begin{array}{l}51 \text { of the colonies } \\
\text { moulds. }\end{array}$ \\
\hline $\begin{array}{l}\text { No. } 3 \\
\text { 1st class }\end{array}$ & $15 / 5 / 31$ & " & 495 & $\mid \begin{array}{r}30 t .7 .5 \\
7.6\end{array}$ & 0.2 & 13,000 & $\begin{array}{l}+ \text { in } \\
1 \mathrm{c} \cdot \mathrm{cm}\end{array}$ & Copious & $\begin{array}{l}\text { Spore- } \\
\text { bearing }\end{array}$ & Very numerous bacteria, & moulds. \\
\hline $\begin{array}{c}\text { No. 3, } \\
\text { 2nd class }\end{array}$ & ," & " & 280 & 7.5 & - & 7,500 & $\begin{array}{l}+ \text { in } \\
2 \text { c.cm. }\end{array}$ & " & $\begin{array}{l}\text { Dacull } \\
\quad,\end{array}$ & $\begin{array}{l}\text { ming. Paramecia } 13 \text { vas. } \\
\text { Identical, but fewer bacteria } \\
\text { and paramecia }\end{array}$ & - \\
\hline $\begin{array}{l}\text { No. } 3 \\
\text { 1st class }\end{array}$ & $3 / 6 / 31$ & ", & 421 & 7.5 & 0.2 & 316 & $\begin{array}{l}\text { Nil in } \\
5 \text { c.cm. }\end{array}$ & Few & Nil & Fair debris and cells, scanty & - \\
\hline $\begin{array}{c}\text { No. 3, } \\
\text { 2nd class }\end{array}$ & " & " & 339 & 7.6 & 0.2 & 1,004 & + in & Numerous & ", & Fair debris and cells, a few & - \\
\hline $\begin{array}{l}\text { No. } 3 \\
\text { ist class }\end{array}$ & $18 / 6 / 31$ & 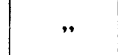 & $5 \div 0$ & 7.7 & 0.2 & 5,898 & $\begin{array}{l}1 \text { c.cm. } \\
+ \text { in } \\
1 \mathrm{c.cm} .\end{array}$ & , & ". & $\begin{array}{l}\text { paramecia } \\
\text { Fair No. of organisms and } \\
\text { parumecia. Many crystals }\end{array}$ & - \\
\hline $\begin{array}{l}\text { No. } 3 \\
\text { 2nd class }\end{array}$ & $"$ & " & 295 & 7.7 & Nil & 4,128 & $\begin{array}{l}+ \text { in } \\
1 \text { c.cm. }\end{array}$ & $"$ & $"$ & " & - \\
\hline $\begin{array}{l}\text { No. } 3 \\
\text { Ist class }\end{array}$ & $20 / 6 / 31$ & •" & 452 & 7.8 & 0.5 & 1,403 & $\begin{array}{l}\text { Nil in } \\
5 \text { c.cm. }\end{array}$ & Very scanty & - & $\begin{array}{l}\text { A few epithelial cells. No } \\
\text { paramecia. Oily matter }\end{array}$ & - \\
\hline $\begin{array}{l}\text { No. } 3 \\
\text { and class }\end{array}$ & $"$ & " & 86 & 7.8 & 0.5 & 496 & o c.cin. & $"$ & - & Similar to lst & - \\
\hline $\begin{array}{c}\text { No. } 3 \\
\text { 1st class }\end{array}$ & $25 / 6 / 31$ & " & 72 & 7.6 & No. apps. & 3,100 & $\begin{array}{c}+ \text { in } \\
0.5 \mathrm{c.cm}\end{array}$ & Numerous & Nil & $\begin{array}{l}\text { Fair amount debris and cells, } \\
\text { living paramecia }\end{array}$ & - \\
\hline $\begin{array}{l}\text { No. } 3 \\
\text { 2nd class }\end{array}$ & , & " & 218 & 7.6 & , & 6,000 & $\begin{array}{c}0.00 .011 \\
,\end{array}$ & " & $"$ & IVing parawecta & - \\
\hline $\begin{array}{l}\text { No. 3, } \\
\text { 1st class }\end{array}$ & $24^{\prime} 8 / 31$ & $"$ & 279 & 7.6 & 0.2 & $7: 0$ & Nil in & " & $"$ & A ferv cells, dead amoebae & - \\
\hline No. 3, & " & ", & 112 & 8.0 & 0.5 & 192 & $\begin{array}{c}5 \text { c.cm. } \\
\text {, }\end{array}$ & Very scanty & $"$ & Fair No. of cells. No amóbae & - \\
\hline $\begin{array}{l}\text { 2nd class } \\
\text { No. 3, } \\
\text { lst class }\end{array}$ & $22 / 7 / 31$ & ", & 445 & 7.5 & 0.2 & 4,480 & $+5 \mathrm{c.cm}$ & Moderate & " & A few cells & 一 \\
\hline $\begin{array}{c}\text { No. } 3 \\
\text { 2nd class }\end{array}$ & $"$ & $"$ & $3: 7$ & 7.6 & $02-$ & $3,2 \mathrm{CO}$ & $\mid \begin{array}{c}-2 \text { c.cin. } \\
\text { Nil in } \\
5 \mathrm{c} . \mathrm{cm} .\end{array}$ & Nil & " & , & - \\
\hline $\begin{array}{l}\text { No. } 1 \\
1 \text { c class }\end{array}$ & $16 / 9 / 31$ & 11.30 a.m. & $2: 3$ & 7.4 & $0.6+$ & 34 & $\stackrel{5 c . c m}{~}$ & $"$ & " & Moderate cells, veg. matter & 一 \\
\hline No. 1. & , & " & 494 & 7.3 & $0.6+$ & 30 & $"$ & $"$ & " & Moderate cells, a few leucocytes & - \\
\hline No. 2 & $28 / 9 / 31$ & $3.0 \mathrm{p.m}$ & 187 & 7.6 & 0.5 & 460 & " & ", & " & Few cells & - \\
\hline $\begin{array}{c}1 \text { st class } \\
\text { No. } 2 . \\
2 n d \text { cless }\end{array}$ & " & $"$ & 249 & 7.5 & 04 & 70 & " & " & " & " & - \\
\hline $\begin{array}{c}\text { No. 3, } \\
\text { st class }\end{array}$ & $16 / 12 / 31$ & $\because$ & 351 & 7.6 & 0.4 & 3 & " & •• & • & " & - \\
\hline No. 1 , & $20 / 132$ & ", & 459 & 7.6 & 0.45 & 33 & " & " & $"$ & " & - \\
\hline No. 2, & $32 / 32$ & ", & 165 & 7.4 & 0.5 & 7 & " & " & $"$ & " & - \\
\hline No. 3 , & $112 / 32$ & , & 197 & 7.6 & 0.2 & 80 & " & ." & " & ", & - \\
\hline $\begin{array}{l}\text { Ist class } \\
\text { No. } 1 \text {, }\end{array}$ & $3: 3: 32$ & " & 139 & 7.6 & 0.4 & 10 & " & " & " & Almost nil & - \\
\hline 1st class & $10 / 3 / 32$ & $4.0 \mathrm{p} . \mathrm{m}$ & 73 & 7.6 & 0.4 & 160 & " & " & " & , & - \\
\hline $\begin{array}{c}\text { No. } 3, \\
\text { 1st class }\end{array}$ & $29 / 3 / 32$ & 3.0 p.m. & 183 & Top 7.6 & 0.4 & $\begin{array}{r}4 \mathrm{CO} \\
10\end{array}$ & , & $\ddot{~}$ & 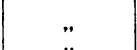 & A few cells, spores & 一 \\
\hline $\begin{array}{l}\text { No. } 1 \text {, } \\
\text { 1st class }\end{array}$ & $31 / 3.32$ & 3.30 p.m. & 191 & $\left|\begin{array}{l}\text { Bot. } 7 \\
\text { Top 7.6 } \\
\text { Bot. ? }\end{array}\right|$ & 0.45 & $\begin{array}{r}10 \\
350 \\
19\end{array}$ & ", & ", & $"$ & $\begin{array}{l}\text { A few er lls and spores } \\
\text { Many cells, no spores }\end{array}$ & - \\
\hline \multicolumn{12}{|c|}{ No'e. - All subsequent samples taken from surface. } \\
\hline No. 1 , & $19 / 5.32$ & 12.30 p.m. & $?$ & 7.6 & 0.4 & 130 & Nil in & Nil & Nil & Feẁ cells & - \\
\hline $\begin{array}{l}\text { Ist class } \\
\text { No. } 1 \text {, }\end{array}$ & ", & , & $?$ & 7.6 & 0.5 & 650 & 5 c.cm. & Fair No. & ” & , & - \\
\hline $\begin{array}{l}\text { 2nd class } \\
\text { No.2. }\end{array}$ & 13/7/32 & $3.30 \mathrm{p} . \mathrm{m}$. & 569 & 7.6 & $0.2-$ & 891 & $+"$ in & Numerous & $"$ & Many cells, a few livin $₫$ para- & - \\
\hline Ist cliss & $13 / 172$ & J.Jo p.in. & 442 & 7.4 & 0.3 & 179 & $\begin{array}{l}1 \text { c.cm. } \\
\text { Nil in }\end{array}$ & Moderate & $m$ & $\begin{array}{l}\text { mecia, algae } \\
\text { Very little disis few }\end{array}$ & Moulds 15 \\
\hline $\begin{array}{l}\text { 2nd class } \\
\text { No. } 1\end{array}$ & 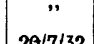 & $"$ & $\begin{array}{l}442 \\
432\end{array}$ & 7.4 & $\begin{array}{l}0.3 \\
0.4\end{array}$ & 112 & $5 \mathrm{c.cm}$. & Very scanty & $n$ & $\begin{array}{l}\text { some spores } \\
\text { Almost nil }\end{array}$ & Mouras 10 \\
\hline lst class & $20 / 7 / 32$ & & 432 & 7.4 & 0.4 & 356 & $"$ & very scaiciy & $"$ & Alinost in & 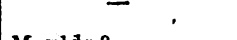 \\
\hline $\begin{array}{c}\text { No. 2, } \\
\text { 2nd class }\end{array}$ & , & , & $?$ & 7.2 & 0.4 & 356 & " & ", & " & & Moulds 8 \\
\hline $\begin{array}{c}\text { No. 3, } \\
\text { Ist elass }\end{array}$ & $14 / 9 / 32$ & ., & 717 & 7.4 & 0.3 & 380 & + in & Scanty & " & Fair debris and cells & - \\
\hline No. 3, & ". & " & $3 ! 1$ & 7.5 & 0.3 & 840 & $\begin{array}{l}1 \mathrm{c.cm} . \\
. "\end{array}$ & " & ״ & ". . " & - \\
\hline No. 2 , & $15 / 11 / 32$ & • & 96 & Top 7.6 & 0.6 & 91 & Nil in & Nil & , & Almost nil, a few cells & - \\
\hline lass & & & & Bòt. 7.8 & 0.5 & 42 & $\begin{array}{c}5 \mathrm{c.cm} . \\
.\end{array}$ & , & - & Very little; rather more than & - \\
\hline \multirow{2}{*}{$\begin{array}{l}\text { No. } 3, \\
1 \text { st class }\end{array}$} & $6 / 2 / 33$ & ," & 217 & Top 7.7 & 0.3 & 2,700 & + in & Few & 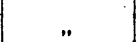 & Fair No. of cells, a few spores & Some moulds. \\
\hline & & & & Bot. ? & $?$ & 963 & Nil in & Very few & " & Fair No. of cells, no spores & - \\
\hline \multirow{2}{*}{$\begin{array}{l}\text { No. } 3 \\
\text { ist class }\end{array}$} & $23 / 2 / 33$ & .' & $18 \hat{3}$ & Top 7.6 & 0.5 & 316 & $"$ & ,. & " & Almost nil & - \\
\hline & & & & Bot. ? & $?$ & 100 & , & None & n & Moderate cells & - \\
\hline $\begin{array}{l}\text { No. } 1 \text {, } \\
\text { st class }\end{array}$ & $15 / 3 / 33$ & 12 noon & 563 & 7.5 & 0.4 & 524 & " & Very few & n & Moderate debris and cells & 一 \\
\hline
\end{tabular}


TABLE OF RESULTS (continued)

\begin{tabular}{|c|c|c|c|c|c|c|c|c|c|c|c|}
\hline Bath & Date & Time & $\left|\begin{array}{c}\text { No. of } \\
\text { Bathers }\end{array}\right|$ & $p \mathbf{H}$ & $\begin{array}{l}\text { Chlorine } \\
\text { in Parts } \\
\text { per } \\
\text { Million }\end{array}$ & $\begin{array}{l}\text { Quanti- } \\
\text { tative. } \\
\text { Colonies } \\
\text { in c.cm. }\end{array}$ & B. coli & Streptococci & B. welchii & Centrifuged Deposit & Remarks \\
\hline $\begin{array}{c}\text { No. } 2 \\
\text { 1stclass }\end{array}$ & $12 / 4 / 33$ & 12 noon & 262 & 7.6 & 0.4 & 930 & $\begin{array}{l}\mathrm{Nil} \mathrm{in} \\
5 \mathrm{ccm}\end{array}$ & Fair No. & Nil & Very little debris, few cells & - \\
\hline $\begin{array}{l}\text { No. } 2, \\
\text { 2nd class }\end{array}$ & " & ", & 340 & 7.6 & 04 & 420 & l. & A few & " & Very little debris, fair No. cells & - \\
\hline $\begin{array}{l}\text { Nad } \\
\text { No. } 3, \\
\text { 1stocias }\end{array}$ & $15 / 5 / 33$ & 3.30 p.m. & 552 & 7.5 & 0.5 & 6,00 & + in & Very few & " & Fair amount debris, few cells & - \\
\hline $\begin{array}{l}\text { No. 3, } \\
\text { 2nd class }\end{array}$ & $"$ & ", & 276 & 7.5 & 0.5 & 7,340 & $\begin{array}{c}+ \text { in } \\
0.5 \mathrm{c.cm}\end{array}$ & ," & " & $\begin{array}{l}\text { Fair amount debris, numercus } \\
\text { cells }\end{array}$ & - \\
\hline $\begin{array}{l}\text { No. } 1, \\
\text { 1st class }\end{array}$ & $29 ; 5 / 33$ & • & 550 & 7.3 & 0.4 & 1,170 & $\begin{array}{l}+ \text { in } \\
2 \text { c.cm. }\end{array}$ & Few & " & Very little debris, few cel's & - \\
\hline $\begin{array}{l}\text { No. 1, } \\
\text { 2nd class }\end{array}$ & $"$ & 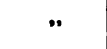 & 459 & 7.3 & 0.4 & 1,220 & $\begin{array}{l}+ \text { in } \\
1 \mathrm{c.cm}\end{array}$ & $"$ & $"$ & , & - \\
\hline $\begin{array}{l}\text { No.? } \\
\text { 1st class }\end{array}$ & $20 / 6 / 33$ & . & 349 & 7.6 & $0.5++$ & 12 & $\begin{array}{l}\text { Nii in } \\
5 \text { c.cm. } \\
\text { No }\end{array}$ & No growth & ״ & $\underset{\text { cells }}{\text { Very little debris, very few }}$ & $\begin{array}{l}\text { "ote. No grow th in } \\
\text { B.S. B. + } 5 \text { c.cm. cm. } \\
\text { water. No growth }\end{array}$ \\
\hline $\begin{array}{c}\text { No. } 2 \text {, } \\
\text { 2nd class }\end{array}$ & $"$ & • & 367 & 7.5 & 0.5 & 312 & $\begin{array}{l}\text { Nil in } \\
5 \text { c.cm. }\end{array}$ & Nil & • & Very little debris, fair No. cells & $\begin{array}{l}\text { in glucose broth. } \\
\text { iote.-Good growth } \\
\text { of water bacteria } \\
\text { in all B.S.B. tubis }\end{array}$ \\
\hline $\begin{array}{l}\text { No. } 3 \\
\text { 1st class }\end{array}$ & $9 / 8 / 33$ & 4 p.m. & ऽ8 & 7.4 & 0.3 & 1,820 & $"$ & , & " & Very little debris, moderate & - \\
\hline $\begin{array}{l}\text { No. } 3 \text {, } \\
\text { 2nd class }\end{array}$ & $"$ & $"$ & 380 & 7.6 & 0.3 & 5,760 & $"$ & " & + & $\begin{array}{l}\text { Fair amount debris, many } \\
\text { cells }\end{array}$ & $\begin{array}{l}\text { B. welchii in } 25 \\
\text { c.cm. }\end{array}$ \\
\hline $\begin{array}{l}\text { No. 2, } \\
\text { lst claqs }\end{array}$ & $: / 9 / 33$ & 3 p.m. & 293 & 7.6 & 0.35 & 1,360 & " & • & Nil & Very little debris, few cells & - \\
\hline $\begin{array}{l}\text { No. } 2 \text {, } \\
\text { 2nd class }\end{array}$ & ., & ", & $?$ & 7.6 & $\begin{array}{c}0.6 \\
\text { (nearly) }\end{array}$ & 736 & " & • & $"$ & $"$ & - \\
\hline
\end{tabular}

\section{Alkalinity and Nitrogen Content}

Alkalinity was usually found to be constant around a $p \mathrm{H}$ of 7.5 ; but on one occasion it appeared possible that a complaint of conjunctival irritation at a time when the chlorine was low might have been caused by excessive alkalinity. It is obvious that a continuously circulating water is likely to contain soluble material derived from bathers, although the coagulant added precipitates and removes the albuminous products. Little work has been done on this point and we have performed no tests. The Ministry of Health report quotes 0.8 gram of nitrogen and 1.3 grams of chlorides per bather. These figures are suggestive ; and it is worth considering how far such substances may become disagreeable, may act as culture media, and may diminish the action of chlorine during the rush hours 'in hot weather. It must be remembered that the water is rarely emptied away and replaced in continuous filtration baths.

\section{Bacteriology}

The examination of the bacterial content of the water presents problems of particular interest. It obviously is absurd to look for sterile water, at any rate with chlorine disinfection, since a tolerable concentration of chlorine requires time to operate. It is only possible to diminish to a very high degree the risk of infection; in no kind of human intercourse can such risk be eliminated entirely. Mallmann and Cary have shown that the number of bacteria found in the water of baths which are chlorinated depends on how rapidly the water is examined. In like manner we have tested simultaneously the water in the bath itself, in the outflow pipe before filtration, and after filtration but before chlorination. We find that the water in the outflow pipe contains many fewer organisms than the bath itself, indicating that the exposure of the organisms to the chlorine has been effective in staying them. Moreover, the organisms in the outflow pipe are almost all spore-bearing air forms. A still further diminution occurs after the sand filtration, and the water returned to the bath is, for practical purposes, sterile. Probably the best measure of efficiency of the bath plant would be the test of outflow and inflow water, as well as bath water proper.

A remarkable difference was found in the bacteria numbers in water at the bottom and at the surface of the bath. Our earlier records are of bottom water, but as bathers are chiefly inhabiting surface water this was later tested. It was found that the surface organisms might be forty times as numerous as the deep ones. This is accounted for not only by contamination of the surface by bathers, but also by the air contamination.

While the organisms likely to be involved in otitis and conjunctivitis are streptococci and pneumococci, testing for these organisms is difficult. The water of baths invariably contains numbers of harmless moulds, and organisms of the subtilis and mesentericus type. These rapidly outgrow such organisms as the streptococcus, which often fails to grow, although seen in centrifuged deposits. The extension of the work of Fleming to bathwater analysis, and the use of inhibitory substances in culture media, would be of great value. We isolated haemolytic streptococci and Streptococcus viridans from one bath (not in the Westminster City Council area) by culture of a deposit in glucose broth and plating of the mixed culture on blood agar. Many other attempts, with grossly contaminated bath water, failed. The only other reference to its isolation found was that quoted by Davis, who states that it was once isolated by Griffiths by mouse inoculation. Examinations were therefore directed towards the estimation of the total numbers of organisms, and the presence of $B$. coli and of $B$. welchii. It will be noted that the number of organisms is, as a rule, far in excess of the figure of "less than 100 per c.cm." suggested as reasonable by Thresh, Beale, and Suckling in their authoritative monograph on water examination. Similarly, we have searched for the presence of $B$. coli in $5 \mathrm{c} . \mathrm{cm}$. of water and in less volumes, whereas these authors suggest 50 c.cm.; and we have examined for $B$. welchii in $25 \mathrm{c.cm}$. instead of $50 \mathrm{c.cm}$. volumes. However, these authors definitely state that their samples are taken at a depth of three feet; and, as has already been stated, we find such a depth to show far fewer organisms.

While the actual number of organisms may be fallacious as an indication of impurity in the water, they do provide a measure of the general disinfection of the water. Reference to the protocols will show that at 0.2 part per million of chlorine, bacterial numbers regularly rise. The occasional appearance of relatively large numbers with higher concentration of chlorine may, of course, be related to actual contamination by bathers, but is also susceptible of other explanation. On certain occasions the chlorine had only just been raised to its observed value 
at the time of testing; in others we noted that the vast majority of organisms were of one type. On one cccasion an actively motile chromogenic organism was almost the sole organism present; on others various types of moulds. It is eminently possible that seasonal or atmospheric conditions may produce air contaminations by chlorine-resistant, non-pathogenic forms. On the whole, however, when there is a large number of bacteria, $B$. coli and B. welchii are likely to be found, and this was particularly brought out in our control tests (not recorded here) of non-chlorinated baths.

\section{SUMMARY}

This series of investigations into the public bath waters of the Westminster City Council covers a period of just over three years.

For eighteen months of this period the water was taken from the situation of the outflow grid at the deep end, and therefore represents the water almost immediately prior to its treatment by the filter plant. In a sense this water is a fair average sample of the water that has been subjected to the full effects of chlorination plus contact with the contaminating human bodies, and with air, bacteria, etc. For a second eighteen months the water was taken from near the surface, where the water was most in contact with the human bodies and aerial contaminants. It is thought that, generally speaking, the bacterial content of this layer is higher than that taken from the depths, and this is what might be expected. Thus, while this surface water represents what one might term the " local efficiency ". of the chlorination as regards the individual bather, the deeper water at the outflow represents the general efficiency of the filtration and chlorination of the whole mass of bath water, before passing through the filter once more. Both are obviously of great importance, but from the point of view of public health the surface water is probably the most important.

While the numbers of the bathers at any given period do not appear to affect in any constant way the proportion of bacteria found, the season of the year does seem to show a variation, the numbers of bacteria being fewer in the winter months.

Sterilization is imperfect when the chlorine figure is below 0.3 part per million, and no bath water should have so low a value. When a chlorine figure of over 0.5 part per million exists, it will be found that the bathers complain of smarting eyes, and nausea if the water is swallowed. It will further be found that the atmosphere of the bath is nauseating, and even irritating. We regard the figure mentioned in the Ministry of Health report-namely, 1.3 parts per million-as being a proportion of chlorine quite intolerable in practice. The figure to be aimed at, therefore, is $\mathbf{0 . 5}$ part of chlorine per million parts of water, no more, and not less than 0.3 part per million on any account.

While the accusation may be made that our bacteriological tests do not take into account the catarrhal organisms and the meningococci, it is fair to assume, from a knowledge of their life-history on artificial media, that the proportion of chlorine in the bath would almost instantly render them innocuous, particularly in the case of the meningococcus. It would seem probable that such organisms are much more likely to be distributed by gross contamination of the towels by nasal mucus, particularly where young children are concerned (schools).

Finally, it seems highly desirable that some automatic device should be employed to maintain constant chlorination of the water at a proper figure, instead of the chlorine figure of the water being obtained by a method of human trial and error, which is the only one at the moment employed, so far as we know.
Bibl.IOGRAPHY

Mallmann, W. L., and Cary, W., jun.: Study of Bacteriological Methods of Testing and Means of Disinfecting Water with Chlorine, Amer. Journ. Pub. Health, xxii, No. 1, 35

Thresh, J. C., Beale, J. F., and Suckling, E. V.: The Examination of Waters and Water" Supplies, London, J. and A. Churchill, fourth edition, p. 690.

Ministry of Health: The Purification of the Water of Swimming

Baths, London, H.M. Stationery Office, 1929, p. 34.
An Investigation into the Bacterial Pollution of Swimming Baths, Journ. R.A.M.C., February, 1933, $1 \mathrm{x}$, No. 2.

\section{Memoranda MEDICAL, SURGICAL, OBSTETRICAL}

\section{A CASE OF SYPHILITIC SPONDYLITIS \\ (With Special Plate)}

Syphilitic spondylitis is of sufficient rarity to warrant the publication of the following case.

J. V., a male aged 37 years, and married, gave a history of urethral discharge fifteen years previously. This had lasted about six weeks, and was treated with medicine only. About six years ago pain developed in the lower part of the back, especially on stooping. This gradually increased in duration and intensity until it was constantly present, being worse on movement and at night. For three years the pain has affected the back of the thighs also. The patient has been losing weight and his appetite has been very poor. On examination there was no scar indicating healed chancre on the genitals. There was tenderness over the spines of the twelfth thoracic, first, second, third, and fourth lumbar vertebrae, and rigidity of the lumbar spine. Movement in bed caused pain, and the patient could hardly sit or stand erect. The blood Wassermann was strongly positive. $X$-ray examination showed increased density of the third, fourth, and fifth lumbar vertebrae, with flattening of the bodies. Osteoarthritic bridges joined the articular margins. There was no evidence of damage to the spinal cord.

\section{Comment}

The absence of a history of primary' or secondary syphilis has little importance in the diagnosis of osseous lesions. Stokes ${ }^{1}$ found that 64 per cent. of his cases gave no history of a primary sore and 87.3 per cent. no history of secondary manifestations. Many (25 per cent.) gave a history of urethral discharge only. Genital scars are similarly uncommon. The diagnosis rests on (a) a strong positive blood Wassermann reaction, $(b)$ the $x$-ray picture, and (c) a striking response to specific therapy. Of secondary importance are associated syphilitic cutaneous lesions or scars. It must be borne in mind that such conditions as a round-celled sarcoma may show improvement under anti-specific treatment. Treatment presents no pitfalls. A Herxheimer reaction is rare in these cases and the response to specific therapy rapid. In this case iodides were given by the mouth with liposoluble bismuth intramuscularly. Within forty-eight hours the patient enjoyed an uninterrupted sleep, and in a week was able to sit up without pain. The tenderness on pressure also rapidly disappeared. Further improvement occurred on the administration of neoarsphenamine. The prognosis is good. Resistant cases do occur, but, with the exception of the $x$-ray findings, which constitute a fixed scar comparable to the Argyll Robertson pupil, one may expect complete clinical and serological cure. Some decrease of the condensation of the vertebrae is to be expected, and, in fact, this has already been demonstrated in films taken two months after the commencement of treatment.

We wish to thank Dr. Bromley for the illustration accompanying this note.

A. Wilson Gill.

North Staffordshire Royal Infirmary. A. D. FRAZER. 